\title{
Mevsimlik Tarımda Çocuk İşçiliğini Azaltmak İçin Bir Model Önermesi: 'Eğitime Erişim ve İletişim Birimi’nin Kurulması*
}

\author{
A Model Proposal for Reducing Child Labor in Seasonal Agriculture: Establishment of the 'Access to \\ Education and Communication Unit'
}

\section{Sedat BENEK \\ Recep BAYDEMÍR}

a Prof. Dr. Harran Üniversitesi, Şanlıurfa, Türkiye,

sbenek@harran.edu.tr ORCID: 0000-0002-5221-9683

b Doktora Öğrencisi, Harran Üniversitesi, Şanlıurfa, Türkiye, recepbaydemir@outlook.com ORCID: 0000-0002-6263-5242

\begin{abstract}
ÖZ
Çocuk iş̧̧i sorunu, geçmişten günümüze süre gelen dünyanın ve Türkiye'nin temel sorunlarından birisi olmayı sürdürmektedir. İLO'nun 2020 tahmin raporuna göre, tüm dünyada \%70'i tarım işlerinde çalışmak üzere toplam 160 milyon çocuk işçi bulunmaktadır. TUİK'in 2019 yılı verilerine göre ise, Türkiye'de 720 bin çocuk işçi bulunmakta ve bunların da \%30.8'i de tarım işlerinde çalışmaktadır. Bugüne kadar çocuk işçiliği ile ilgili yapılan araştırmalar ve kurumlarca derlenen veriler, çocuk işçiliği konusunun Türkiye'nin ve özellikle GAP Bölgesi'nin "kangreni" haline geldiğini göstermektedir. Buradan hareketle, bu çalışmanın temel amacı; 'Mevsimlik Tarımda Çocuk İşçiliğini Azaltmak İçin Eğitime Erişim ve İletişim Birimi’nin kurulması gerektiği konusunda bir model önerinin ortaya konulmasıdır. Önerilen bu model, sadece eğitime erişim sorunu yaşayan öğrencilere ve ailelerine yönelik sistemli ve kayıtlı bir çalışma modelidir. Böylelikle bu çalışmada, söz konusu sistemde her uzmanın belli sayıda bakabilecek öğrenci sayısıyla ilgilenmesi, çocukların ailelerine gerekli bilgilendirmeler yapılarak bir farkındalığın oluşturulması gerekliliği vurgulanmaktadır. Netice itibariye, söz konusu modelin hayata geçmesi durumunda hem çocuk işçiliğinin azaltılabileceği hem de çocukların daha kolay eğitime katılmalarının mümkün olabileceği tahmin edilmektedir.
\end{abstract}

Anahtar Kelimeler: Mevsimlik Tarım İşçiliği, Çocuk İşçiliği, Eğitim Hakkı, GAP Bölgesi, Şanliurfa.

\begin{abstract}
The problem of child labor continues to be one of the main problems of both the world and Turkey. According to the 2020 estimation report of the ILO, there are a total of 160 million child workers worldwide, $70 \%$ of whom work in agriculture. According to TUIK's 2019 data, there are 720 thousand child workers in Turkey and $30.8 \%$ of them work in agriculture works. Researches on child labor conducted to date and datapp compiled by relevant institutions show that child labor is a "gangrene" in Turkey and especially in the GAP Region. Therefore, the main purpose of this study is to put forward a model proposal on the need to establish an Access to Education and Communication Unit for Reducing Child Labor in Seasonal Agriculture. Thus, in this study, it is emphasized that in this system, each specialist is interested in the number of students who can take care of a certain number, and the awareness of the children by providing the necessary information to their families. As a result, this study predicts that both the reduction of child labor and the easier participation of children in education can be possible if the model is implemented.
\end{abstract}

Keywords: Seasonal Agricultural Work, Child Labor, Education Right, GAP Region, Sanliurfa.

\footnotetext{
*Bu makalede bilimsel araştırma ve yayın etiği ilkelerine uyulmuştur. / In this article, the principles of scientific research and publication ethics were followed.

Atıf-Reference: Benek, S. \& Baydemir, R. (2021). Mevsimlik Tarımda Cocuk İsçiliğini Azaltmak İçin Bir Model Önermesi: 'Eğitime Erișim ve İletișim Birimi’nin Kurulması. Bitlis Eren Üniversitesi Sosyal Bilimler Dergisi, 10 (2), 45-57.
} 


\section{GíRiş}

Toplumların tarihsel ve kültürel kimliklerinden bağımsız olmayan çocuk ve çocukluk kavramı, Turnbull'un, Mbuti Pigme Topluluğu üzerinde yaptığı çalışmalarda gösterdiği gibi, çocuk tanımı göreceli olsa da günümüzde en yaygın olan “yetişkin olmayanlar" şeklinde yapılmaktadır. Çocukluk, bebeklikten, daha doğrusu doğarken başlar ve 18 yaşına kadar devam eder (Nurgül Çetinkaya,1997, 77- 82'den aktaran Güçlü, 2016: 2-3). İnsan yaşamının doğal ve değişmez bir parçası olan çocukluk, aynı zamanda, sosyo-kültürel bir kavrama da işaret eder. Bu nedenle diğer toplumsal kavramlar gibi norm ve değerler tarafindan belirlenir. Nitekim erken yaşta iş hayatına girmek zorunda kalan çocukların içinde bulunduğu durumun altında yatan dinamikler incelendiğinde, çocukluğun sadece biyolojik bir kavram olmadığı aynı zamanda psikolojik, sosyolojik ve tarihsel bir kavram (Güçlü, 2016: 3) olduğu anlaşılacaktır.

Sosyolojik bir olgu olarak çocuk işçiliği, güncel bir sorun veya konu değildir. Çünkü insanlık tarihinin pek çok evresinde onunla karşılaşmak mümkündür. Zira, Milattan Önceki (M.Ö.) dönemlerde yaşayan Sümerler ve Asurlar gibi medeniyetlerde çocukların işçi olarak çalıştırıldıkları bilinmektedir (Güzel, 2016: 1993). "Çeşitli kaynaklarda piramitlerin inşası sırasında Mısır'da çocuk işçilerden de yararlanıldığı iddia edilmektedir. Ayrıca Romalılar döneminde de tıpkı köleler gibi çocuk işçilerin kullanılması oldukça yaygın bir durumdur. Çocuk işçiliği tarihsel süreçte çok eski dönemlere kadar uzansa da, bugün hukuki boyutta algılandığg kadarıyla ilk olarak 16. ve 17. yüzyıllarda önemli bir sorun haline gelmiştir. Bunun en önemli sebebi bu yüzyıllarda başta Kuzey Amerika olmak üzere Batı toplumlarında köleliğin yaygınlaşmasıdır. Çocuk işçiliği sorunu 18 . ve 19. Yüzyıllarda Avrupa'da yaşanan Sanayi Devrimi ile birlikte doruk noktasına ulaşmıştır” (Güzel, 2016: 1993). Günümüzde de hem ulusal hem de uluslararası düzeyde çocuk işçiliğini azaltmaya veya bitirmeye dönük gösterilen tüm çabalara rağmen özellikle gelişmemiş veya gelişmekte olan ülkelerde başta olmak üzere toplumsal alandaki en önemli sorunlardan birisi olmayı sürdürmektedir (Efe \& Uluoğlu, 2015: 47; Güzel, 2016: 1993).

Uluslararası Çalışma Örgütü’nün (ILO) tanımına göre, çocuk işçiliği, “çocuğun sağlığını, eğitimini, fiziksel ve zihinsel gelişimini engelleyen, yeteneklerinin gelişmesine engel olan ve çocuğu potansiyelinden ve onurundan yoksun bırakan her türlü çalışma” olarak tanımlanmaktadır (Efe \& Uluoğlu, 2015: 47). Çocuk işçiliği, dünyanın pek çok ülkesinde önüne geçilemeyen temel bir sorun olarak güncelliğini korumaktadır. Bir insanın çocuk yaşta iş hayatına atanması, sadece onun bulunduğu yaştaki ruh ve beden sağlığını değil, aynı zamanda, daha sonraki yaşantısını da olumsuz (Efe \& Uluoğlu, 2015: 47) yönde etkileyeceği muhakkaktır.

Bu sebeple Yıldız (2007: 57)’ın da belirttiği gibi, “Çocuklar, bir toplumun geleceğini oluşturmakta ve onlara yapılan yatırım geleceğe yapılan yatırım anlamına gelmektedir. Her toplumun nihai hedefi sağlıklı, eğitimli ve geleceğe donanımlı nesiller yaratmaktır. Bu nedenle, çocuklarla ilgili sorunlar hem ulusların hem de uluslararası örgütlerin gündeminde öncelikli yer tutmaktadır. Çocukların sokakta ya da işyerlerinde çalışması, giderek artan bir önemle politikacıların, konu ile ilgili çalışma yapan araştırmacıların ve akademisyenlerin ilgi odağını oluşturmaktadır. Yapılan araştırmalar çalışan çocuk sorununun boyutunu, sektörel dağılımlarını, çocukları çalıştırma nedenlerini, çocuk işçiliği ile mücadelede etki edecek yöntemlerin ne olacağını araştırmaya yönelmiştir" (Yıldız, 2007: 57).

$\mathrm{Bu}$ anlamda çocuk işçiliği ile ilgili hem ulusal hem de uluslararası literatürde oldukça güçlü bir birikim olmuştur. Çocuk işçilerle ilgili uluslararası literatürde Uluslararası Çalışma Örgütü olan ILO’nun (International Labour Office) yaptığı konferanslar (1999a; 1999b; 2008; 2011) ve hazırladığ1 raporlar (2002; 2012; 2013; 2017; 2021) literatüre katkı sağlamakla birlikte, bu çalışmalar, özellikle de çocuk işçiliğine ilişkin dünya çapındaki sayısal verileri ihtiva ettiği için sıklıkla başvurulan kaynaklar arasındadır.

Ulusal literatürdeki çalışmalar ise, sokak çocuklarına odaklananlar; mevsimlik tarım işlerinde çalıştırılan çocuklara ve onların emeğine odaklananlar; kayıt dışı istihdam ve gelir vergisi bağlamında olanlar; hukuki mevzuat ve çocuk hakları açısından yaklaşanlar; Türkiye'deki gelir dağılımının eşitsizliğinin bir sonucu olarak yaklaşanlar; bir sorun olarak çocuk işçiliği, bu soruna dair çözüm önerileri ve onunla ile mücadele stratejileri kapsamında olanlar ve Suriyeli çocuk işçiler bağlamında ele alanlar olarak çeşitlenmektedir (Karataş vd., 2016; Benek \& Ökten, 2011; Gülçubuk, 2012; Kalkınma Atölyesi, 2016; Yandık, 2017; Gümrükçüoğlu, 2014; Karaman \& Özçalık, 2007; Küçükkalay vd. 2000; Günöz, 2007; Avşar \& Öğütoğulları, 2012; Erbay, 2013; Efe \& Uluoğlu, 2015; Güzel, 2016).

Görüldüğü gibi çocuk işçiliği pek çok açıdan tartışma konusu yapılmıştır. Dolayısıyla bu çalışmanın literatürdeki diğer çalışmalardan temel farkı, eğitime erişmekte zorlanan veya çalıştırıldığı için okula gidemeyen ve eğitim olanaklarına erişemeyen çocuk işçilerin tekrar eğitime kavuşturulmaları için bir model önerme sunması ve bunu desteklemesidir. Bu çalışmanın temel hedefi de uzun yıllardır Türkiye'de özellikle de GAP Bölgesi'nin neredeyse kangreni haline gelmiş ve kronikleşmiş olan tarımda çocuk işçiliğini azaltmak ve bu çocuk işçilerin bir iletişim kanalı yardımıyla eğitim kurumlarına tekrar entegre olmalarını sağlamaktır.

Bu çalışma, Türkiye'de ve özellikle GAP Bölgesi’nde genelde çocuk işçiliğinde ve özelde ise tarım işlerinde çalıştığı için okula gidemeyen çocukların nasıl tespit edilebileceği ve bu anlamda önerilen modelin nasıl hayata geçirilebileceğini konu edinmektedir.

Dolayısıyla bu çalışma, mevsimlik tarımda çocuk işçiliğini azaltmak için "Eğitime Erişim ve İletişim Birimi’nin Kurulması" modelini önermektedir. Söz konusu bu model, hayata geçtiğinde, çok sayıda çocuk "kayıp kuşak" olmaktan kurtulacak ve çocuk işçiliğinin azaltılması sağlanmış olacaktır. Böylelikle, çalıştırıldığı için eğitim hakkından mahrum kalan 
çocuklar, kolay bir biçimde eğitim haklarını kazanabileceklerdir. Bugünün çocuklarının yarının geleceği olduğu savından hareket edildiğinde, çalışmak zorunda olduğu için eğitimsiz kalan ve dolayısıyla çocukluklarını yaşayamayan ve sağlıklı beslenemeyen çocukların gelecek adına umut vadedemeyeceğini kabul etmemiz gerekir. Bu sebeple çalışmak zorunda kaldığı için okula gidemeyen çocukların tespit edilmesi ve bunların eğitime kazandırılması toplumun geleceği açısından büyük önem arz etmektedir.

\section{DÜNYADA ÇOCUK İŞÇILERIN KITALARA/BÖLGELERE VE SEKTÖRLERE DAĞILIMI}

Dünyadaki çocuk işçilerin sayısına ilişkin kesin olarak verilere ulaşmak zor olmakla birlikte, bu alanda etkin bir kuruluş olan Uluslararası Çalışma Örgütü’nün (ILO) “Küresel Tahminler ve Eğilimler 2000-2012” raporuna göre, 2012 yılı itibariyle tüm dünyada 5-17 yaş grubunda 264 milyon çocuk ekonomik işlerde çalıştırılmakta ve bunların 168 milyonunun ise "çocuk işçi" olarak görülebileceği tahmin edilmektedir. Bu çocuk işçiler içinde de 85 milyon çocuğun tehlikeli işlerde çalıştığ1 belirtilmektedir (ILO, 2013).

ILO’nun 2017 yılında yayınladığı “Küresel Tahminler ve Eğilimler 2012-2016” raporuna göre ise, dünya çapında 5-17 yaş grubunda 152 milyon “çocuk işçi” bulunmaktadır. Bu oran da dünyadaki toplam çocuk nüfusunun yüzde 10'unun “çocuk işçi” olarak çalıştığı anlamına gelmektedir (ILO, 2017).

Yine İLO'nun 2021 yılında yayımlanan Global Estimates, 2020, Trendsandthe Road Forward tahmin raporuna göre, 2020 yılında dünya genelinde 79 milyonu "tehlikeli işlerde" olmak üzere toplamda 160 milyon çocuk işçinin bulunduğu ve bunların da \%70'inin de tarım sektöründe çalıştığı tahmin edilmektedir. Tarımda çocuk işçiliği genel olarak Asya ve Afrika kıtalarında daha fazla yoğunlaşırken, Avrupa ve Kuzey Amerika'da ise en düşük düzeyde olduğu görülmektedir (ILO, 2021: 12-13).

Görüldüğü gibi, çocukların, fiziksel, ruhsal ve duygusal gelişimlerini etkileyen elverişsiz koşullarda çalışması, neredeyse tüm dünya ülkelerini yakından ilgilendiren bir sorun olmaya devam etmektedir (Yıldız, 2007: 57). Nitekim çocuklar, "çok farklı nedenlerle erken yaşta çalışma yaşamına atılmaktadır. Her ne kadar çalışan çocuk sayısı dünya ölçeğinde azalma emaresi gösteriyorsa da oranlar hala azımsanmayacak boyuttadır. Ekonomik ve toplumsal gelişmişlik skalasında geri olan ülkelerde sorun hâlâ ciddiyetini korumaktadır (Yıldız, 2007: 57). Genel olarak Afrika kıtası başta olmak üzere, Latin Amerika ve Asya'daki pek çok ülke bu sorunu yoğun olarak yaşamaktadır.

Dünyada çocuk işçilerinin kıtalara/bölgelere dağılımına bakıldığında gerek “çocuk işçiliği”nin gerekse “en kötü koşullarda çocuk işçiliği’”nin en fazla olduğu kıtaların başında Afrika geldiği görülmektedir. LO’nun 2017 yılındaki raporuna göre, tüm dünyada 5-17 yaş arası çocuk işçiliği genel ortalaması \%9,6 iken, bu oran Afrika'da \%19,6'dır ve dünya ortalamasının iki katından daha fazladır. Yine "En Kötü Biçimlerde Çocuk İşçiliği” oranları genel olarak dünyada \%4,6 iken, bu oran Afrika'da yaklaşık iki kattır $(\% 8,6)$. Çocuk işçiliği oranlarında Afrika’yı sırasıyla, \%7,4 ile Asya ve Pasifik; \%5,3 ile Amerika (çok yoğunlukla Latin Amerika); \%4,1 ile Avrupa ve Orta Asya ve en düşük seviyeyle (\%2,9) Arap devletleri izlemektedir. "En kötü biçimlerde çocuk işçiliği” oranlarındaki kıta/bölge sıralamaları da hemen hemen benzerdir (Şekil 1).

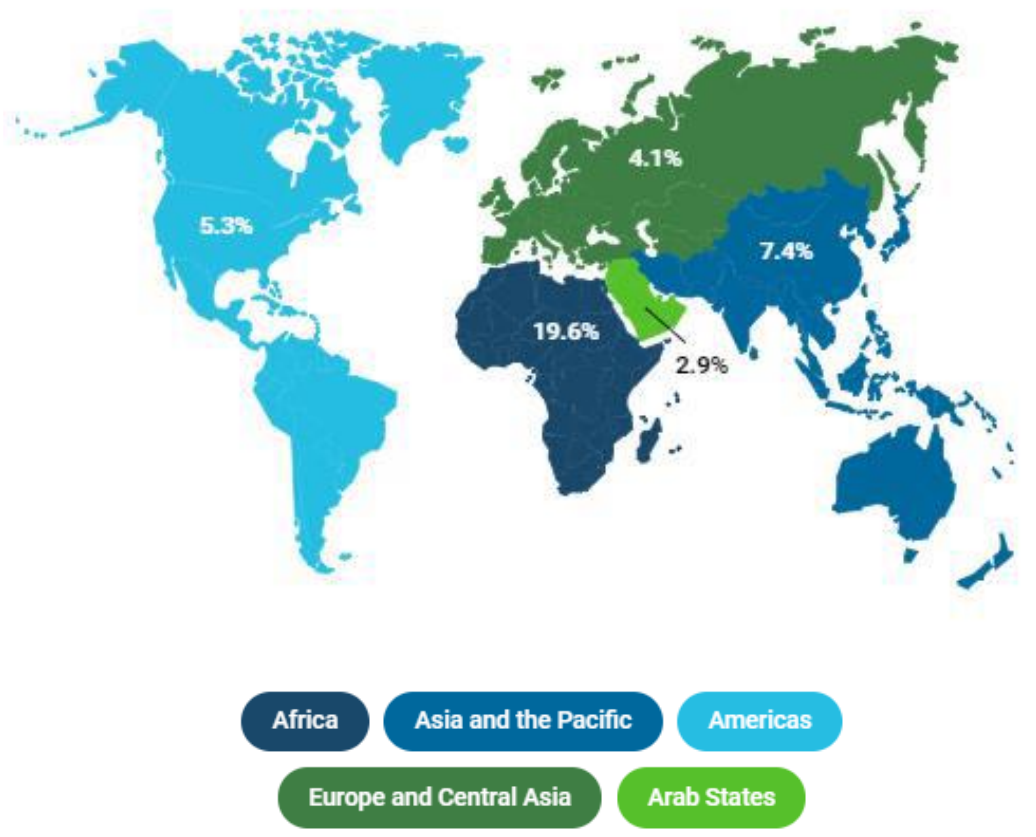

Şekil 1: Kitalara/Bölgelere Göre Çocuk İşçiliği (2017)

Kaynak: (ILO 2017'den aktaran Çöpoğlu, 2018a: 677). 
Tüm dünyada çalışan çocukların ezici bir çoğunluğu tarım sektöründe çalışmaktadırlar. Tarım sektörünü sırasıyla hizmet ve sanayi sektörü izlemektedir. Ancak tarım sektöründe çalışan çocukların sayısı (107.543) hizmet (26.072) ve sanayi (18.007) sektöründe çalışan çocukların sayısının iki katından daha fazladır (Grafik 1).

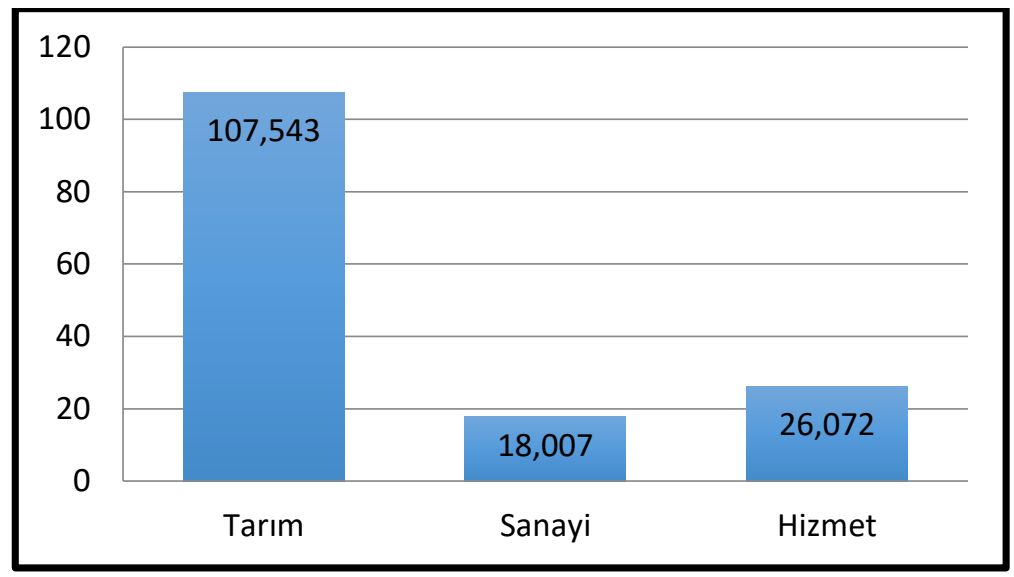

Grafik1: Çalışan Çocukların Sektörlere Göre Dağılımı (5-17 yaş grubu)

Kaynak: ILO (2017).

Çocuk işçilerin dünyadaki dağılımına bakıldığında, dikkat çekici biçimde tüm dünyada çocukların çoğunlukla tarım işlerinde çalıştıkları görülmektedir. Bu oran \%50'den aşağı değildir. Afrika'da işçi çocukların \%85,1'i tarım sektöründe çalışırken, bu oran Avrupa ve Orta Asya ülkelerinde \%76,7, Arap devletlerinde \%60,3, Asya ve Pasifik’te \%57,5, Amerika'da \%51,5'tir. Buna karşılık hizmet sektöründe çalışan çocukların payının en fazla olduğu kıta Amerika kıtası (\%35,3) oluşturmaktadır. Amerika'yı sırasıyla Arap Devletleri (\%27,4), Asya ve Pasifik (\%21,1), Avrupa ve Orta Asya (\%13,6), en sonda da Afrika $(\% 11,2)$ izlemektedir. Dünya kıtalarında/bölgelerinde sanayi sektöründe çalışan çocuk işçilerin tüm sektörler içindeki oranının en fazla olduğu bölge \%21,4 ile Asya ve Pasifik’tir. Asya ve Pasifik'i sırasıyla Amerika (\%13,2), Arap Devletleri $(\% 12,4)$, Avrupa ve Orta Asya $(\% 9,7)$ ve Arap Devletleri $(\% 3,7)$ izlemektedir (Grafik 2).

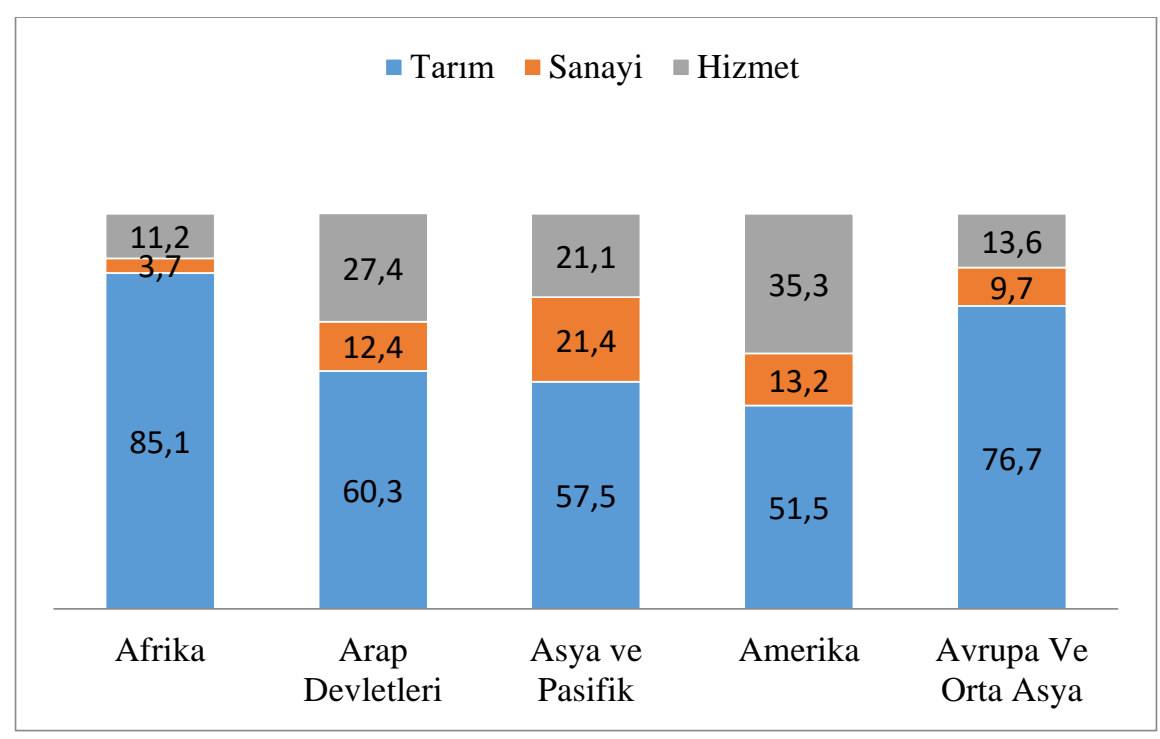

Grafik 2: Çalışan Çocukların Bölgelere ve Sektörlere Dağılımı (5-17 yaş grubu)

Kaynak: ILO (2017).

Dahası, 15-17 yaş arasındaki çocuklar çoğunlukla (\%52,80) sanayi sektöründe çalışırken, 5-11 yaş arasındaki çocuklar da \%55,70 oranla tarım işlerinde çalışmaktadırlar. Böylelikle yaşı daha küçük olan çocuklar tarım sektörüne yığılırken, yaşı biraz daha büyük olanlar sanayi gibi daha ağır işlerde çalıştırılmaktadır (Grafik 3). 


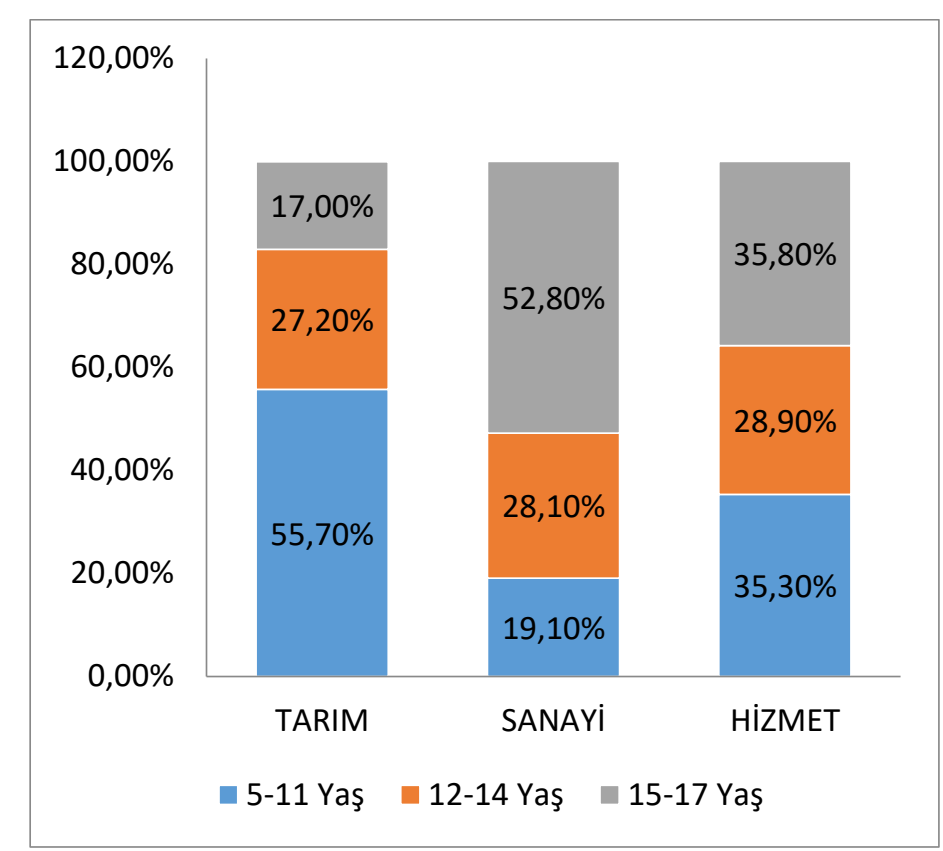

Grafik 3: Yaş Gruplarına ve Ekonomik Sektörlere Göre Çocuk İşçiliği Dağılımı (2017)

Kaynak: ILO (2017).

Yukarıdaki verilerden de anlaşılacağı üzere işsizlik ve yoksulluk, hızlı ve çarpık kentleşme, nüfus artış hızı, eğitim düzeyi (Tunçcan, 2000: 243-249; Çöpoğlu, 2018b: 370-381), göç, gecekondulaşma ve kent işsizliği (Yıldız, 2007: 60) gibi sebepler çocuk işçiliğine olan arzı artırmaktadır.

Gelişmiş, azgelişmiş veya gelişmemiş toplumların neredeyse ortak sorunlarından biri olan çocuk işçiliğinin her şeyden öte bir çocuk hakkı ve çocuğun eğitim hakkı ihlali olduğu unutulmamalıdır. "Çünkü kendi seçimleri olmadan zorla veya zorunlu olarak çalışan çocuklar, en temel hakları olan; çocukluklarını yaşamak, sağlıklı beslenmek, eğitim imkânlarından yararlanmak kısaca geleceğe hazırlanmak haklarından mahrum kalmaktadırlar” (Çöpoğlu, 2018a: 671).

Çocukluk çağını tam olarak yaşayamadan, temel gereksinimleri giderilmeden çok erken yaşlarda çalışma yaşamına atılan, daha doğru bir ifade ile çalıştırılan çocuklar, çeşitli atölyelerde, tarlalarda ya da sokaklarda çalışmak zorunda kalmaktadırlar. Çocuğun içinde büyüdüğü sosyal çevre, ailesinin sosyo-ekonomik durumu, aile içi iletişim, eğitim hizmetinin verildiği okullar gibi, çocukların yetişkinlik çağına daha donanımlı girmesini sağlayan temel faktörler (Yıldız, 2007: 58) olduğu bilinmesine karşıllk, çocuk işçiliğinin geçmişten günümüze toplumun kanayan yarası olarak mevcudiyetini sürdürmesi karşımızda bir gerçek olarak durmaktadır.

\section{TÜRKIYY'DE ÇOCUK İŞÇILERIN SAYISI VE SEKTÖRLERE DAĞILIMI}

\subsection{Türkiye'deki Çocuk İş̧̧ilerin Sektörlere Dağılımı}

Gülçubuk (2012: 79), sosyo-ekonomik göstergeler itibarıyla Türkiye'nin tarım ekonomisi ağırlıklı bir yapıdan sanayi ağırlıklı bir ekonomik yapıya, kırsal alan ağırlıklı bir nüfus yapısından, kentsel ağırlıklı bir nüfus yapısına geçiş sürecinde olduğunu belirterek, bu sürecin de beraberinde olumsuz yan etkileri de ortaya çıkarttığını ve bunun sonuçlarından birisi olarak da tarımda ve diğer sektörlerde ortaya çıkan işgücü olduğunu vurgulamaktadır. Gülçubuk'a göre, başta tarım sektöründe olmak üzere çocuk işçiliğine neden olan temel unsurları şu şekilde sıralamak mümkündür (Gülçubuk, 2012: 79):

$>$ "Göç,

$>$ Bozuk gelir dağılımı,

$>$ Yetersiz eğitim, Eğitimde firsat eşitsizliği,

$>$ Nüfus artışı,

$>$ İşsizlik,

$>$ Yoksulluk,

$>$ Yetişkinlerin işsizliği,

$>$ Mevzuatın eksikliği ve etkin uygulanamaması,

$>$ İşverenlerin çocuk işgücü talebi,

$>$ Ücretsiz aile işçiliği ve

$>$ Tarımda istihdam çocuk işçiliğini belirleyen temel unsurlardır"

Türkiye İstatistik Kurumu (TÜIK) tarafından yapılan “2012 yılı Çocuk İşgücü Anketi” sonuçlarına göre Türkiye'de ekonomik faaliyetlerde çalışan 6-17 yaş grubundaki çocukların oranı \%5,9'dur. Bu da 2012 yılındaki verilere göre, Türkiye'de 
toplamda 890 bin çocuk işçi bulunduğu anlamına gelmektedir (Çalışma ve Sosyal Güvenlik Bakanlığı, 2017). Bununla birlikte, TUİK (Çocuk İşgücü Anketi Sonuçları, 2019)'in verilerine göre Türkiye'de 2019 yılında 720 bin çocuk ekonomik faaliyetlerde bulunmuş ve bunların \%30.8'i tarım sektöründe çalışmıştır.

Çocuklar, fiziki ve psikolojik yapıları gereği ağır işlerde çalışamamaktadırlar. Bu işlerde çalışan çocuklar hem fiziki zorluklar hem de psikolojik sıkıntılar çekmektedir. Zor iş koşullarından dolayı hayatını kaybeden çocuk sayısı azımsanamayacak kadar çoktur. İşçi Sağlığı ve Güvenliği Meclisi (İSİG), hazırladığı bir rapora göre, 2016 yılının ilk beş ayında 18, son 3,5 yılda ise en az 194 çocuk işçi can vermiştir. Çocuk işçiler en çok tarım, inşaat, metal ve ticaret gibi ağır işlerde yaşamını yitirirken, ölüm nedenleri ise en çok servis/trafik kazası, zehirlenme/boğulma, düşme ve ezilme/göçük olarak kaydedilmiştir (http://t24.com.tr/haber/isig-raporundan-cocuk-isci-olumleri-6-yasina-kadar-geriledi,344909).

Çocuk işçilerin çalıştığı iş kolları, inşaat işçisi, atık toplayıcılığı, otomobil tamirciliği, sokak satıcısı, dilencilik, mevsimlik tarım işçisi gibi sektörlerdir. Bu tür işler çocukları eğitimlerinden uzak tutmakta ve olması gereken yaşam standartlarının altında yaşamaya itmektedir.

Dünyadaki çocuk işçiliğinin sektörel bazdaki dağılımına bakıldığında, en çok tarım sektöründe yoğunlaşmanın olduğu görülmektedir. Çocuk işçilerin \%58,6'sı tarım sektöründe, \%32,3'ü hizmet sektöründe ve \%7,2'si sanayi sektöründe çalışmaktadır. Ancak Türkiye'deki çocuk işçiliğinin 2006 ve 2012 yılları arasındaki dağılımına bakıldığında, \%36,63 ile \% 44,70 arasında değiştiği görülmektedir. Bununla birlikte sanayi ve hizmet sektöründe çalışan çocukların oranı kısmen düşerken, tarım sektöründe çalışan çocukların oranı artmıştır (Grafik 4).
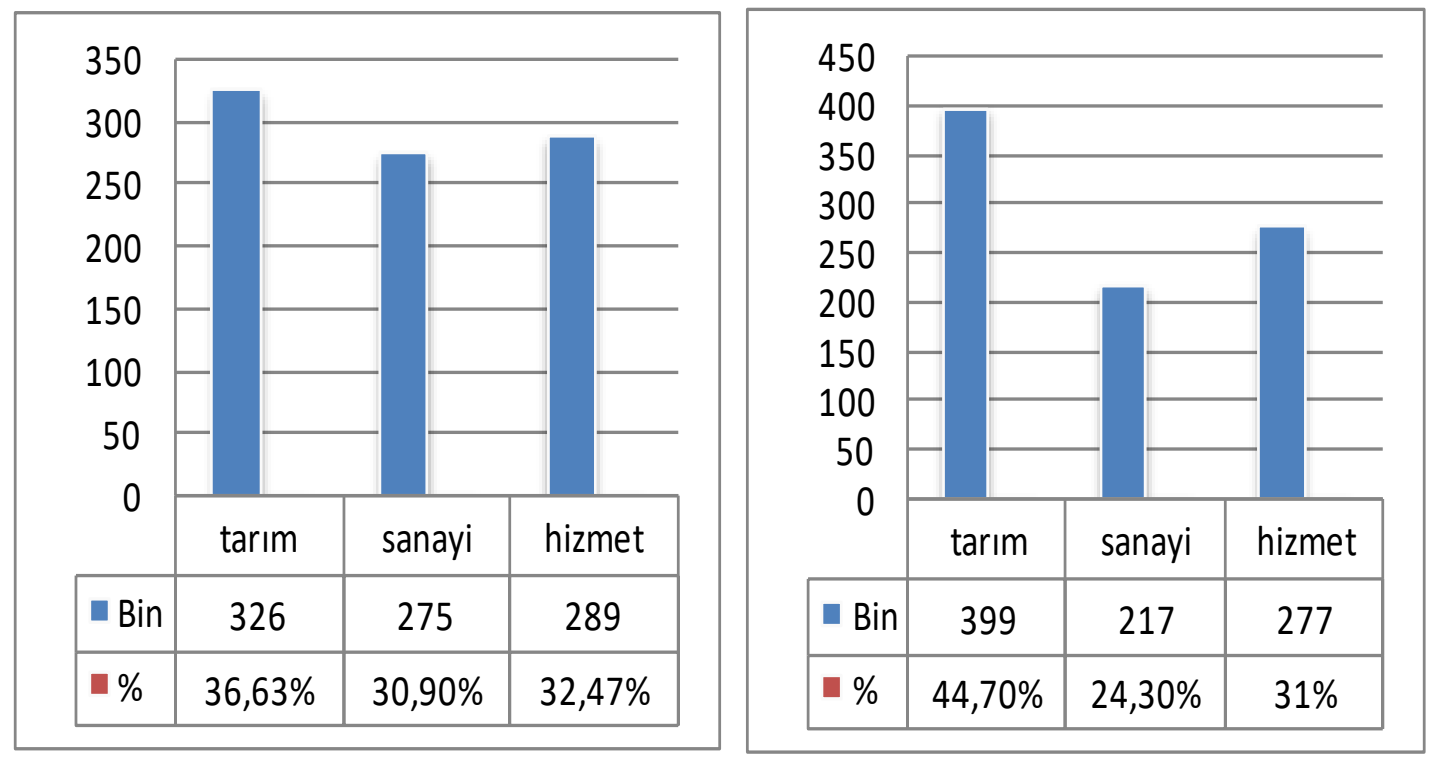

Grafik 4: Çocuk İşçiliğinin Türkiye'de Sektörel Dağılımı (5-17 Yaş 2006-2012)

Kaynak: TÜİK (2006-2012).

Çalışan çocukların cinsiyet bazlı sektörel dağılımlarına bakıldığında tüm sektörlerde yoğunlukta erkek çocukların çalıştırıldığı ama erkek çocukların çalıştırılma paylarının en fazla tarım ve hizmet sektöründe olduğu görülmektedir. Benzer biçimde kız çocuklarının da tarım sektöründe sıklıkla çalıştırıldıkları görülmektedir. Sektörel bazdaki çalışma oranları içinde erkek ve kız çocuklarının çalıştırılma oranları arasındaki fark en fazla hizmet ve sanayi sektörlerinde olduğu anlaşılmaktadır.

\subsection{Mevsimlik Tarım İşlerinde Çalışan Çocuklar}

Gerek dünyada gerekse Türkiye'de çocuk işçiliğinin yaygın biçimlerinden biri de şüphesiz ki mevsimlik tarımda çocuk işçiliğidir. "Kendi tarım işletmelerinden yeterli gelir elde edemeyen az topraklı ve/veya topraksız aileler geçimlerini sağlayabilmek ve çalışabilmek amacıyla daha fazla tarımsal iş olanağı bulunan yörelere mevsimlik/dönemlik göç ederek iş aramaktadır. Bu işçiler, tarımsal üretimin kendine özgü niteliklerinden dolayı zor koşullarda çalışmakta ve yaşam mücadelesi vermektedir. Mevsimlik tarım işçisi aileler çalışma yerlerine giderken ekonomik ve sosyal zorunluluklardan dolayı çocuklarını da götürmektedir. Böylece, çocuklar aile ekonomisine katkı nedeniyle yaşlarına uygun olmayan tarımsal işlerde çalışmaktadır. Türkiye'de 'mevsimlik' iş göçü, özellikle sanayi bitkileri olan pamuk, tütün ve şekerpancarı tarımında yoğunlaşmaktadır." (Gülçubuç, 2012: 79) (Fotoğraf 1). 


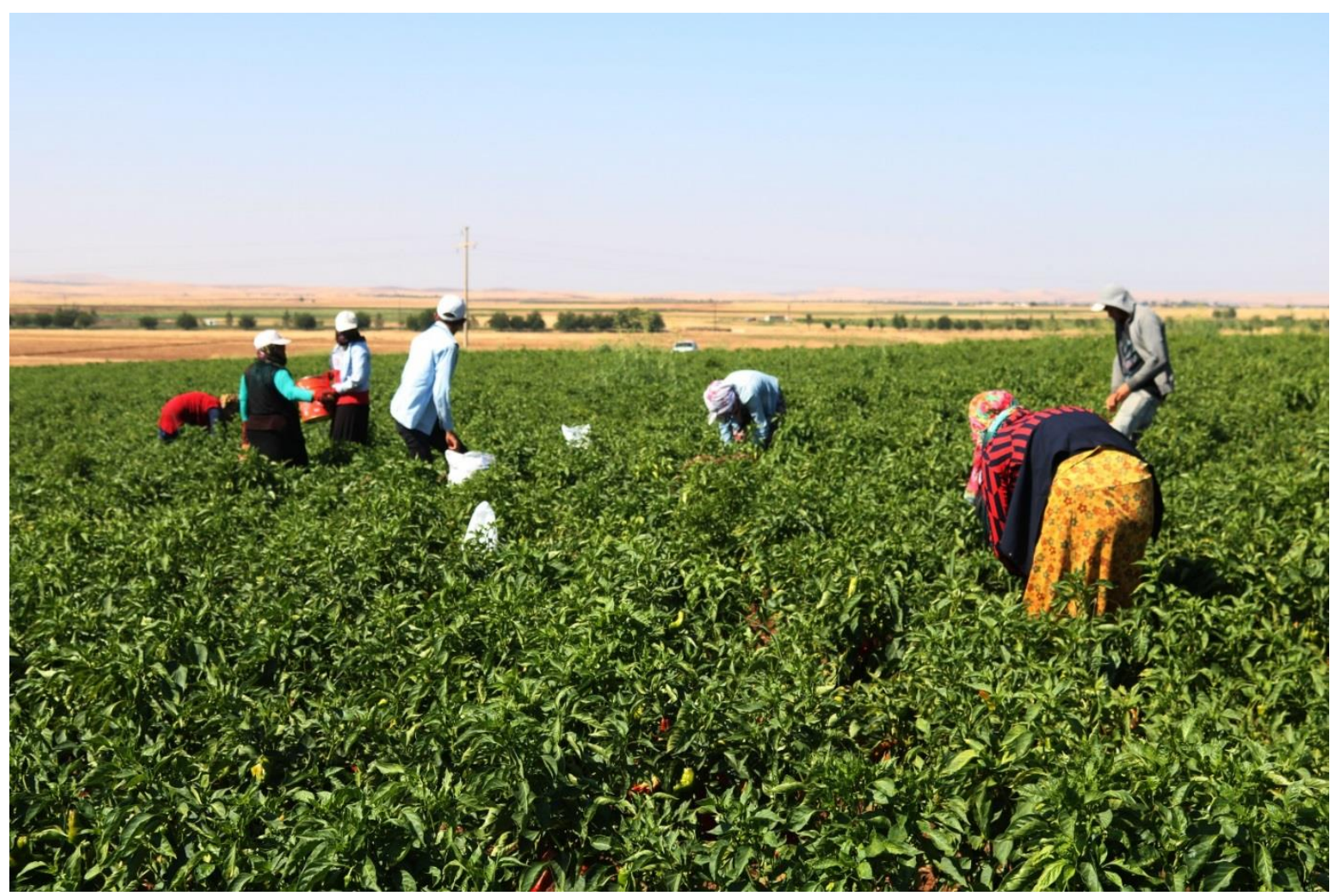

Fotoğraf 1: Eğitim Döneminde Olmalarına Rağmen Okula Değil Tarlaya Giden Çocuklar

Tarımda “en kötü biçimde çalışan çocuk işçiliği” ile ilgili olarak Gülçubuk’un (2012) kendi çalışmasında belirttiği gibi, daha önce kendisi ve arkadaşları tarafından 2003 yılında Adana'nın Karataş İlçesinde pamuk tarlalarında mevsimlik işçi olarak çalışan çocuklar ile ilgili olarak yapılan bir çalışma çarpıcı sonuçlara ulaşmıştır. Söz konusu araştırmanın bazı sonuçları şu şekilde sıralanabilir:

> "Mevsimlik tarım işçiliği, sadece köylerden gelenlerin değil, kentlerden de çalışmaya gelen bireylerin bir uğraşısıdır. Araştırma kapsamındaki çocukların \%50,8'i kent, \%49,2'si köy doğumludur. Mevsimlik tarımsal işgücü hareketliliği özellikle Güneydoğu Anadolu Bölgesinde yaygındır. Çocukların \%58,5’i bu bölgedeki illerde (Adıyaman, Şanlıurfa, Diyarbakır, Gaziantep) doğmuşlardır.

$>$ Çocuklar genelde çok çocuklu ailelerdendir. Özellikle, köy kökenli çocukların ailelerinde çocuk sayısı biraz daha fazladır. Çocukların yarısından fazlası $(\%$ 67,6) en az 6 kardeşe sahiptir. Çocuk başına düşen ortalama kardeş sayısı ise (kendisi de dâhil) 6,6 olarak bulunmuştur.

$>$ Çocukların \%75,8'i günde en az 12 saat çalışmaktadır. Bu oran kızlarda biraz daha $(\% 76,9)$ yükssek çıkmıştır. Hesaplamalarda çocukların günde ortalama 11,7 saat çalıştıkları belirlenmiştir. Bu çalışma saatleri, çoğunlukla çocuğun iradesi dışında, baba ve/veya annesinin istekleri doğrultusunda biçimlenmektedir. Çünkü amaç aileye daha fazla gelir sağlamaktır. Çocukların \%99,3 gibi çok büyük çoğunluğu haftanın her günü, \%0,7'si ise haftada 5 gün çalışmaktadır. Ayrıca erkeklerin \%100'ünün, kızların ise \%98,7'sinin haftanın her günü çalıştığı görülmektedir.” (Gülçubuk, 2012: 81-83).

Mevsimlik tarım işlerinde çalışan çocuklar; genellikle aileleriyle birlikte veya kendi başına bir ücret karşılığında bir başkasının yanında daha doğrusu tarlasında çalışan çocukları kapsamaktadır. Mevsimlik tarım işlerinde çalışan çocuklar, çoğunlukla bulundukları bölgelerden başka bölgelere veya illere mevsimlik olarak başta bitki çapalama, ot alma, hasat vb. bitkisel üretim işlerinde çalışmak üzere kendi yerleşim yerlerinden ayrılarak 4-7 ay arasında çalışanlardan oluşmaktadır. Bu sebeple mevsimlik tarım işlerinde çalışan çocuklar, konaklama ve dolayısıyla barınma, beslenme, su ve sanitasyon, sağlık, eğitim gibi konulardan olumsuz olarak en fazla etkilenen gruptur. Bu sektörde çalışan çocuklar kayıt dışı çalışmaktadırlar ve bu sebeple iş güvenliğine sahip değiller. İş güvenlikleri yani sigortaları olmadığı için, yaralanmaları veya hastalanmaları durumunda ödeme alamazlar ve bundan dolayı da bir yeri veya kişiyi dava edemezler (Gülçubuç, 2012: 80). Daha da önemlisi, mevsimlik gezici tarım işlerinde çalışan çocuklar, kendi imkanlarıyla iyileşmek zorunda kalmakta ve böylelikle tek başına bu sorunun üstesinden gelmektedirler.

\section{4. "EĞITTIME ERIŞSIM VE ILETIŞiM BIRIMI'NIN" KURULMASI}

Benek ve Ökten'nin "Mevsimlik Tarım İşçilerinin Yaşam Koşullarına ilişkin Bir Araştırma: Hilvan İlçesi (Şanlıurfa) Örneği” isimli çalışmalarında Türkiye genelinde yapılan bir araştırmaya atıf yaparak, Türkiye'deki mevsimlik tarım işçilerinin \% 53,1'inin Güneydoğu Anadolu Bölgesi'nde yer aldığını saptamıştır (Yıldırak, 2003: 59'dan aktaran Benek ve Ökten, 2011: 65). 
Türkiye'deki mevsimlik tarım çocuk işçiliğinin de oranları buna benzer şekildedir ve Türkiye'de mevsimlik tarımda çocuk işçiliğinin en fazla olduğu bölge GAP Bölgesi'dir.

Genelde Türkiye'de özelde GAP Bölgesi ve dolayısıyla Şanlıurfa ilinde de mevsimlik tarım işçiliğinde özellikle çocuklar için okula gidememe yani eğitime erişim önemli bir sorun olmaya devam etmektedir. "Çünkü Mayıs-Kasım ayları arasında gerçekleşen tarım işçiliği nedeniyle çocuklar eğitimini ya yarıda bırakmakta ya hiç başlamamakta ya da belli bir düzeyden sonra devam edememektedir. Çocukların \%47,2'si okuryazar, \%34,2'si ise "ilkokul mezunu"dur. "Okur-yazar olmayan”ların oranı ise, \%12,2'dir. Çocuklar arasında mevsimlik tarım işçiliğinde çalışmadan dolayı ilkokulu bitirmeden terk edenlerin oranı \%20,0'dir" (Gülçubuk, 2012: 83). 2012 TUİK verilerine göre, çocukların gerek ev işlerinde gerekse ekonomik getirisi olan işlerde çalıştıklarından dolayı eğitime devam edemedikleri görülmektedir (Tablo 1).

Tablo 1: Türkiye'de Çocukların Eğitime Katılımı ve Çalışma Durumuna Göre Dağılımı

\begin{tabular}{|c|c|c|c|c|c|}
\hline \multicolumn{6}{|c|}{$\begin{array}{c}\text { 6-17 Yaş Grubu Çocuk Sayısı } \\
15.247 \text { (Bin) }\end{array}$} \\
\hline \multicolumn{3}{|c|}{$\begin{array}{l}\text { Okula Devam Eden } \\
13.950(\text { Bin })\end{array}$} & \multicolumn{3}{|c|}{$\begin{array}{c}\text { Okula Devam Etmeyen } \\
1.297 \text { (Bin) }\end{array}$} \\
\hline $\begin{array}{c}\text { Ekonomik } \\
\text { Faaliyetlerde } \\
\text { Çalışan }\end{array}$ & $\begin{array}{c}\text { Ev İşlerinde } \\
\text { Faaliyette } \\
\text { Bulunan }\end{array}$ & Çalışmayan & $\begin{array}{c}\text { Ekonomik } \\
\text { Faaliyetlerde } \\
\text { Çalışan }\end{array}$ & $\begin{array}{c}\text { Ev İşlerinde } \\
\text { Faaliyette } \\
\text { Bulunan }\end{array}$ & Çalışmayan \\
\hline $\begin{array}{c}445 \\
(\% 2,9)\end{array}$ & $\begin{array}{c}7.000 \\
(\% 45,9)\end{array}$ & $\begin{array}{c}6.504 \\
(\% 42,7)\end{array}$ & $\begin{array}{c}448 \\
(\% 2,9)\end{array}$ & $\begin{array}{c}503 \\
(\% 3,3)\end{array}$ & $\begin{array}{c}346 \\
(\% 2,3)\end{array}$ \\
\hline
\end{tabular}

Kaynak: TUİK, 2012.

Türkiye'de mevsimlik tarım işçiliğinin en fazla olduğu bölge GAP Bölgesi'dir. Bu bölgedeki iller içinde de tarımda çocuk işçiliğinin en fazla olduğu il Şanlıurfa'dır. Nitekim, Şanlıurfa Mevsimlik Tarım İşçileri İzleme Kurulu (ŞAMTİ)'ndan alınan bilgilere göre 19.06.2017 tarihi itibariyle mevsimlik tarım işçisi olarak çalışmaya giden 11,250 öğrenci bulunmaktadır. TÜIKK verilerine (2017) göre ise Şanlıurfa ilinde 4326 çocuk işçi bulunmaktadır. Şanlıurfa ilinde gerçekten mevsimlik tarım işçiler içerisinde öğrencilerin sayısının daha fazla olduğu tahmin edilmektedir.

Şanlıurfa İl Milli Eğitim Müdürlüğünden (2019) alınan verilere göre 15.136 öğrenci mevsimlik tarım işlerinde çalışmak üzere göç ederken (Tablo 3), Şanlıurfa Mevsimlik Tarım İşçileri İzleme Kurulu’na (2019) göre, 22.500 öğrenci (Tablo 2) tarım işlerinde çalışmaktadır.

Tablo 2: Şanlıurfa İlinde İlçeler Bazında Mevsimlik Tarım İşçisi Öğrenci Verileri

\begin{tabular}{lllll}
\hline İLÇELER & İlkokul & Ortaokul & Lise & Toplam \\
\hline EYYÜBIYYE & 1.914 & 3.038 & 496 & 5.448 \\
\hline AKÇAKALE & 603 & 855 & 69 & 1.527 \\
\hline HALİLLIYY & 600 & 374 & 42 & 1.016 \\
\hline SíVEREK & 241 & 281 & 304 & 826 \\
\hline SURUÇ & 305 & 216 & 260 & 781 \\
\hline HARRAN & 271 & 429 & 3 & 703 \\
\hline VİRANŞEHİR & 50 & 106 & 254 & 410 \\
\hline HİLVAN & 170 & 89 & 29 & 288 \\
\hline CEYLANPINAR & 147 & 24 & 3 & 174 \\
\hline BİLECIK & 25 & 22 & 3 & 50 \\
\hline HALFETI & 6 & 18 & 3 & 27 \\
\hline TOPLAM & 4.332 & 5.452 & 1.466 & 1.250 \\
\hline
\end{tabular}

Kaynak: Şanlıurfa Mevsimlik Tarım İşçileri İzleme Kurulu, Haziran 2017, Şanlıurfa.

Eyyübiye, Viranşehir, Siverek, Akçakale, Haliliye ve Harran ilçelerinde mevsimlik tarım işlerinde çalışmak üzere bulundukları yerden göç eden öğrenci sayısı 13.689'dur. Bu ilçelerden giden öğrenci sayısı toplam giden öğrenci sayısının \%90'nını oluşturmaktadır (Şanlıurfa İl Milli Eğitim Müdürlüğü, 2019). Bu veriler, söz konusu ilçelerde önerilen "Eğitim ve İletişim Birimi”inin kurulmasının ne kadar elzem olduğunu göstermektedir. Ayrıca, önerilen bu modelin Şanlıurfa'da hayata geçirilmesi durumunda, önceliğin bu ilçelere verilmesi gerektiğini de ortaya koymaktadır (Tablo 2-3). 
Mevsimlik Tarım İşçileri Yuvarlak Masa Toplantısı verilerine göre Şanlıurfa'da yaklaşık 40.000 tarım işçisi ailelerin çocuğu tam olarak okula erişememektedir (2016: 7). Şanlıurfa ilinde ilköğretim, ortaöğretim ve lise aşamasında olup ama hiç okula gitmeyen veya gidemeyen, çalışmak üzere okulu erken bırakan veya okula geç başlayan toplam öğrenci sayısı ile ilgili net bir veri olmamakla birlikte 50.000 civarında olduğu tahmin edilmektedir. Söz konusu çocukların büyük bir kısmı başta tarımda olmak üzere yalnız veya ailelerinin yanında "çocuk işçi” olarak çalışmaktadırlar.

Tablo 3: Şanlıurfa'da Mevsimlik Tarım İşlerinde Çalışmak Üzere Göç Eden Öğrencilerin İlçe Bazlı Dağılımları

\begin{tabular}{l|l}
\multicolumn{1}{l|}{ İLÇE } & \multicolumn{1}{l}{ SAYI } \\
\hline EYYÜBİYE & 6.282 \\
VİRANŞEHIR & 2.135 \\
SIVEREK & 1.671 \\
AKÇAKALE & 1.342 \\
HALILIYE & 1.229 \\
HARRAN & 1.030 \\
HİLVAN & 466 \\
SURUÇ & 364 \\
CEYLANPINAR & 363 \\
BİRECİK & 216 \\
BOZOVA & 19 \\
KARAKÖPRÜ & 16 \\
HALFETİ & 3 \\
TOPLAM & 15.136 \\
\multicolumn{1}{c}{ Kaynak: Şanllurfa İl Milli Eğitim Müdürlüğü, 2019.}
\end{tabular}

Şanlıurfa'nın Hilvan ilçesinde Benek ve Ökten (2011) tarafından yapılan bir alan çalışmasında 523 mevsimlik tarım işçisine uygulanan anket sonuçlarında, katılımcıların \%37.5'i okuryazar değil, \%53.2'si de ilkokul mezunu (Benek \& Ökten, 2011: 660) olduğunu dolayısıyla bu sektörde çalışan ailelerin eğitim düzeylerinin ne kadar düşük olduğunu göstermektedir. Aynı çalışma (2011: 664) bölgede özellikle erkek çocuğa duyulan gereksinim ve bu nedenle en az bir erkek çocuğu oluncaya kadar doğumların sürdürülmesi sebebiyle yüksek doğurganlığın olduğunu ve hane halkı başına düşen ortalama çocuk sayısını 7,2 olduğunu saptamıştır.

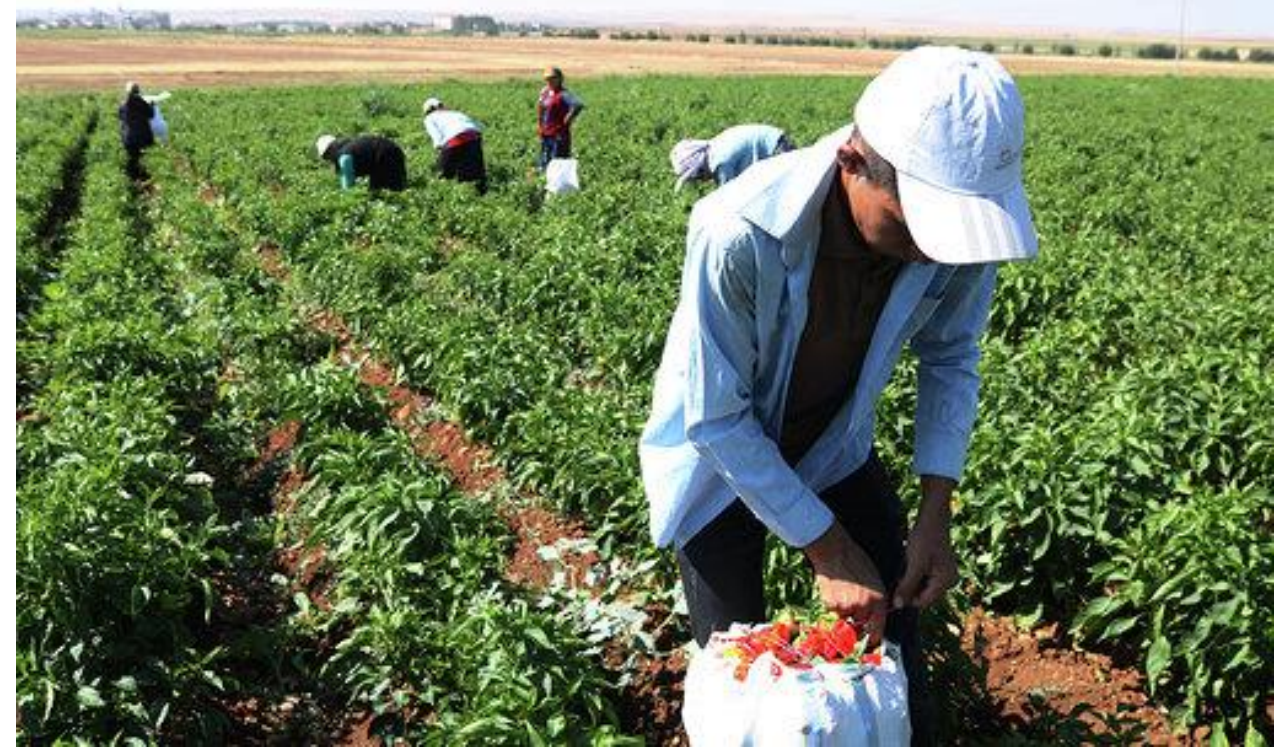

Fotoğraf 2: Şanlıurfa'da Okul Çağında Olup Tarlada Ailesiyle Birlikte İsot Toplayan Çocuklar

Ailelerin çok çocuklu ve yoksul olmaları sebebiyle mevsimlik tarım işlerinde çalışırken zorunlu olarak kendi çocuklarını da işgücüne katmaktadırlar. Bu durumda çocukların eğitim hayatlarından koparılmasına veya eğitim hayatlarının sağlıklı biçimde 
yürümemesine sebep olmaktadır. Mevsimlik çocuk işçiliğinin fazla olduğu Şanlıurfa ilçelerinden biri olan Hilvan ilçesinde yapılan bir araştırmada (Benek \& Ökten, 2011: 665), mevsimlik tarım işlerinde çalışan ailelerin, okul çağında olup da okula gidemeyen çocuk oranının $(\% 11,9)$ çarpıcı derecede yüksek olduğunu ortaya koymuştur. Benzer biçimde aynı çalışma (Benek \& Ökten, 2011: 667), mevsimlik tarım işlerinde çalışan ailelerin \% 76.3'ünün eğitim çağında olan çocuklarını, okul kapanmadan bir süre önce alındığını ve okul açıldıktan belli bir sonra tekrar gittiğini ortaya koymuştur (Fotoğraf 2).

Yönetmenliğini Sedat Benek ve Mustafa Uluç’un yaptığı ve genel olarak GAP Bölgesi’ndeki çocuk işçiliğinin ve dolayısıyla eğitime erişememe durumunu açık biçimde ortaya kayan Şakha isimli belgesel de bölgenin adeta kanayan yarasına dönüşen çocuk işçiliğini konu edinerek bir farkındalık yaratmaya çalışmaktadır. 10 kişilik bir ailenin kız çocuğu olan ve sabah çok erken saatlerden akşam saatlerine kadar isot üretiminde, yoksul olan ailesinin geçimine katkı sağlamak için, çalışan Şanlıurfalı Şakha isimli kız çocuğunu konu edinen ve hem ulusal hem de uluslararası düzeyde pek çok ödül alan kısa belgesel filmde, Şakha;

Arkadaşlarımla buluşurken veya konuşurken, hep istediğim meslek, öğretmen veya polis olmaktı. Hep hayal ettiğim gibi olmak isterdim. Onların [arkadaşlarımın] hayalleri vardı. Ben kendi hayallerimi gerçekleştiremediğim için üzgünüm. Çalıştığım için, aileme yardımcı olmak istediğim için okuyamadım. Arkadaşlarıma bakıp onları kıskandığım oluyor. Yine çalışmaya mecburdum. Annemi öyle görünce ben de çalışmak zorunda kaldım. Okulumu isot yüzünden bıraktım. Okuluma odaklanamıyordum. Evin tek kızı olduğum için evin işleriyle uğraşıyordum. Sonra biber işi de çıkınca okul mu iş mi, hangisine odaklanacağımı şaşırdım. En büyük hayalim ailemi kurtarmaktı ama olmadı. Hayal kurmayı isterdim ama artık hayal kurmuyorum. Çünkü olmayacağını bildiğim için hayal kurmuyorum. Hayal kurmaktan vazgeçtim artık. Hayattan soğudum. Sekiz kardeşiz hepimiz aynı odada kalıyoruz. Ne benim ne abilerimin ne de kardeşlerimin odası var (Şakha kısa belgesel filmi, 2017).

Diyerek hem izleyenleri duygulandırıyor hem de bölgedeki çocuk işçiliği sebebiyle okula gidemeyen çocukların mevcut durumunu bu sözleriyle özetliyor.

Şüphesiz ki, çocuk işçilerin yaşadığı en büyük sorunlardan birisi de eğitime erişim sorunudur. Çocuklar, en temel hakkı olan eğitim hakkından çalıştıkları iş nedeniyle mahrum kalmaktadır. Çocukların "kayıp nesil” olmaması ve bunun önlenmesi için eğitim kurumlarına yönlendirilmesi gerekmektedir.

Bu çalışmadaki verilerin de ortaya koyduğu gibi, gerek genel olarak tüm sektörlerde çalışan çocuk işçiler gerekse mevsimlik tarım işlerinde çalışan ve bu sebeple eğitim faaliyetinden uzak kalan çocukların sayısı hayli yüksektir. Hem çocuk işçiliğini azaltmaya dönük hem de çocuk işçilerin eğitimi ile ilgili yapılmış çalışmaların ileri sürdüğü önerileri vardır. Ancak bu çalışmadaki öneri geliştirilen bir model öneridir. Bu model "Eğitime Erişim ve İletişim Birimi”nin kurulması modelidir. Bu sayede, mevsimlik tarım işlerinde çalıştığ 1 için ya sürekli ya da kısmi olarak eğitim faaliyetlerinden uzak kalan çocukların bizim önerdiğimiz "Eğitime Erişim ve İletişim Birimi” modeli ile eğitime kazandırabiliriz.

Ancak, bu model ile sorunun nasıl çözülebileceğini veya sorunun çözümüne nasıl katkı sunulabileceğini ortaya koyabilmek için, öncelikle tarımda mevsimlik işlerde çalışan çocukların okula gitmeme/gönderilmeme nedenleri ile bu çocukların karşılaştıkları temel sorunların neler olduğunun bilinmesi gerekir. Böylesi bir yaklaşım, söz konusu sorunların, önerilen modelle nasıl çözülebileceği ortaya konulabilinecektir.

Genelde GAP Bölgesi özelde ise Şanlıurfa ilinde mevsimlik tarım işlerinde çalışan çocukların okula gitmeme/gönderilmeme nedenleri genel hatlarıyla şu şekilde sıralanabilir:

$>$ Bölgede ve Şanlıurfa'da kız çocukları ücretsiz aile işçisi olarak görülmekte, erken yıpranan annenin görevlerini üstlenmektedir.

> Bu kızlar 12-13 yaşlarına geldiklerinde evin bütün işlerini yapmakla, kardeşlerine bakmakla sorumlu olan birer haline gelmektedir.

$>$ Zorunlu eğitim olan ilköğretime dahi büyük bir kısmı gidememekte, gidenler ise çok büyük zorluklarla okumaktadır.

$>$ Şanlıurfa ilinde yaşayan kızlar halen erken yaşta evlenmekte/evlendirmektedir.

$>$ Dolayısıyla erken yaşlarda evlendirilen kız çocukları, erken yaşlarda anne olmakta ve normal yaşam süresinden çok daha kısa yaşamaktadırlar.

$>$ Okula gidememe sorunun altında yatan en büyük nedenlerden biri eğitim/bilinç düzeyidir.

> Belirli bir eğitim seviyesine ulaşamayan ve okula gidip kendi yaşıtları ile normal ilişkiler kurmaktan yoksun kalan ebeveynler, bu geleneksel anlayış ile kendinden sonra gelen nesilleri de bu şekilde yetiştirmektedirler.

Görüldüğü gibi, çocukların okula gitmeme/gönderilmemelerinin başında, ebeveynlerin eğitim durumları, ailelerinin sosyoekonomik durumları, geleneksel toplumdaki ataerkillik algısına bağlı olarak kız çocuklarına toplumun bakış açısı ve bu bakış açısının bir sonucu olarak erken yaşta evlilik gibi nedenler gelmektedir. Benzer biçimde, genelde GAP Bölgesi'nde özelde de Şanlıurfa ilinde mevsimlik tarım işlerinde çalışan çocukların temel sorunsalları da yine genel hatlarıyla şu şekilde sıralanabilir:

$>$ Aileler mevsimlik tarım işçisi olarak çalıştıkları için çocuklarını da beraberinde götürüp çalıştırmakta,

$>$ Ailelerde okuma-yazma oranı düşük olduğu için çocuklara eğitimlerinde yardımcı olamamakta,

$>$ Hane sayısı kalabalık olduğu için çocuklar rahat ders çalışamamakta,

$>$ Okullarda sınıflar kalabalık olduğu için öğretmenler çocuklara yeterli zaman ayıramamakta, 
> Ailedeki ve okuldaki birtakım yanlış tutum ve davranışlardan dolayı, çocuklar birey olma, başarma, özgüven, farkındalık ve aidiyet duyguları gelişememekte,

> Sosyalleşme süreci sağlıklı gerçekleşmeyen çocuklarda fiziksel, zihinsel ve bedensel sorunlar yaşanabilmektedir.

Bu yüzden, hem çocuk işçiliğiyle ve dolaylı olarak yoksullukla hem de doğrudan çocukların eğitim süreçlerine katılımını sağlamak için denetimi, yönetimi ve desteklenmesi bütünüyle Milli Eğitim Bakanlığı başta olmak üzere valilik ve belediyeler tarafından sağlanması gereken bir birimin kurulması gerekmektedir. Gerek GAP Bölgesi’nde gerekse Şanlıurfa ilinde özellikle de mevsimlik tarım işçi ailelerinin yoğun bulunduğu illerde/ilçelerde/semtlerde/mahallelerde "Eğitime Erişim ve İletişim Birimi" adında bir birim kurulmalıdır. Bu birim, sadece okula erişim sorunu yaşayan öğrencilere yönelik sistemli ve kayıtlı çalışmalar yapmalıdır. Söz konusu sistemde her uzman belli sayıda bakabilecek öğrenci sayısıyla ilgilenmeli, çocukların ailelerine gerekli bilgilendirmeler yaparak bir farkındalık oluşturmalıdır. Bu birimde çalışacak olan uzmanların seçim işlemlerini bu birimden de sorumlu olacak olan Milli Eğitim Bakanlı tarafından yapılmalıdır. Seçilecek olan uzmanın, sosyoloji, psikoloji, sosyal hizmetler, hemşirelik, çocuk gelişimi, eğitim bilimi alanları başta olmak üzere pek çok alandan alınabilir. Sorumlu kurum tarafından seçilen uzmanlar, mevsimlik tarım işlerinden dolayı okula gidemeyen çocukların yoğunlukta olduğu yerlere gönderilmelidir. Daha sonra bu uzman söz konusu çocukların ailelerini belirlemeli ve onlara ulaşarak onlara ilişkin tüm kayıtları almalıdır. Tıpkı sağlık alanındaki Aile Hekimliği’nde hekim hastasını nasıl tanıyorsa, önerilen bu birimde çalışacak olan uzman kişi de sorumlu olduğu tüm çocukları ve yakın çevrelerini yani ailelerini bilmelidir. Bu durumda, ailede hasta birisinin olması durumunda onu sağlıla ilgili kuruluşlara yönlendirebilmeli, ilgilendiği ailede engelli birisi varsa onu sosyal hizmetler ile ilgili kuruluşlara yönlendirmeli, işsizleri İş Kurumu'na, yaşı geçmiş ama okumak isteyen aile fertlerini açık öğretim okullarına yönlendirmelidir. Uzman, en önemlisi de ailenin bulunduğu yerde devlet desteğiyle yerel ekonomiler güçlendirilerek ailelerin ekonomik bağımsızlıklarını bir noktadan sonra kazanmalarını sağlamak için girişimlerde bulunmalıdır.

Bu durumda Eğitime Erişim ve İletişim Birimi’nin Görevleri şunlar olacaktır:

$>\mathrm{Bu}$ birimde görevli olacak olan kişi sadece sorumlu olduğu çocuğu değil aynı zamanda ailesinde takibinden sorumlu tutulmalıdır. Uzman kişi, ailenin tüm sosyo-ekonomik durumlarını kaydetmeli ve sorumlu olduğu tüm ailelere ait bilgilerin olduğu ve bu bilgilere kolaylıkla erişebileceği bir veri tabanı oluşturmalı,

$>$ Terklerin erken önlenmesi en iyi tedavidir gerçeğinden hareketle, okulda gayretli, başarmak isteği olan öğrenciler ihtiyaç duydukları ders konularında takviye sağlanmalı,

$>$ Çeşitli faaliyetlerle kültürel ve sosyal yönden gelişmelerine yardımcı olunmalı,

$>$ Okulda okuma ve ders çalışma odası düzenlenerek öğrencilerin buradan faydalanması teşvik edilmeli,

$>$ Rehber Danışman aracılığ 1 ile aileler eğitim, cinsiyet ayrımcılığg gibi konularda bilinçlendirilmeli,

$>$ Okul-Aile Birliğinin yapacağı çalışmalarla da okul- aile ilişkisini güçlendirilmeli,

$>$ Ayrıca, okuldaki öğretmenlere eğiticinin eğitimi dersleri de verilmelidir.

Çalıştıkları için okula gidemeyen mevsimlik tarım çocuk işçilerinin "Eğitime Erişim ve İletişim Birimi”" ile eğitime nasıl kazandırılabileceğine ilişkin bazı önerileri şöyle sıralamak mümkündür:

$>$ Öğretmenlere/ebeveynlere/çocuklara yönelik bilgilendirme/bilinçlendirme yapılacak,

$>$ Öğrencilerin ve ailelerin burslar ve diğer imkanlar hakkında bilgi almasını sağlayacak.

> Okulu bırakmak zorunda kalmış kişilerin açık ilköğretim, ortaöğretim ve üniversitelere kayıt yaptırmalarını sağlayacak,

$>$ Okul ile hiçbir bağı kalmamış kişileri mesleki eğitim kurslarına yönlendirmek ve eğitim aldıkları konularda istihdamlarına yardımcı olunacak,

$>$ Bölgede doğmuş ve eğitim almış örnek teşkil edebilecek emsallerle öğrencileri ve ailelerini bir araya getirecek (Sizden biri "Başarılı Hikayeler"i sunmak gibi).

\section{SONUC}

Eğitime erişmekte zorlanan veya çalıştırıldığı için okula gidemeyen ve eğitim olanaklarına erişemeyen çocuk işçilerin tekrar eğitime kavuşturulmaları için bir model önerme sunması ve bunu desteklemesi açısından önem arz eden bu çalışma, temelde uzun yıllardır Türkiye'de özellikle de GAP Bölgesi’nin neredeyse “kangreni” haline gelmiş ve kronikleşmiş olan tarımda çocuk işçiliğinin azaltılması ve bu çocuk işçilerin bir iletişim kanalı yardımıyla eğitim kurumlarına entegre olmalarının sağlaması hedeflemiştir. Dolayısıyla bu çalışma, mevsimlik tarımda çocuk işçiliğini azaltmak için "Eğitime Erişim ve İletişim Birimi’nin Kurulması" modelini önermektedir. Bu model, hayata geçtiğinde çok sayıda çocuk "kayıp kuşak" olmaktan kurtulabilir. Böylelikle hem çocuk işçiliğinin azaltılması hem de çalıştırıldığı için eğitim hakkından mahrum kalan çocukların daha rahat biçimde eğitim haklarını kazanabilmeleri sağlanmış olacaktır.

Bugünün çocuklarının yarının geleceği olduğu savından hareket edildiğinde eğitimsiz kalan, çocukluğunu yaşayamayan ve yaşı gereği sağlıklı beslenemeyen çocukların gelecek adına umut vadedemeyeceğini kabul etmemiz gerekir. Bu sebeple çalışmak zorunda kaldığı için, çalışıp okula gidemeyen çocukların tespit edilmesi ve bunların eğitime kazandırılması toplumun geleceği açısından büyük önem arz etmektedir.

Çocukların neden çalıştırıldığı sorunsalının arkasında tek bir sebep olmadığı için çözümüne yönelik çalışmalar ve öneriler de elbette ki tek boyutlu olmayacaktır. Dolayısıyla bu çalışmanın önerdiği, “Erişsim ve İletişim Birimi”nin kurulması durumunda 
çalışmak zorunda kaldığı için okula gidemeyen çocukların okula entegre edilmeleri ve böylelikle mevsimlik tarım işlerinde çalıştığı için, eğitim faaliyetlerinden uzak kalan çocukların eğitime daha çok kazandırılacağı tahmin edilmektedir.

Türkiye'de bugüne (2021) kadar, mevsimlik tarımda çocuk işçiliğini azaltarak çocukların eğitime erişimlerini sağlamak ve çocukların çocukluklarını yaşayabilmek için ya proje bazlı çalışmalar ile sınırlı kalınmış ya da çıkarılıp ama bir türlü hayata geçirilmemiş mevzuat ile yetinilmiştir. Böylesi bir yaklaşım da ciddi boyutlara varan çocuk işçiliğini ve çocukların eğitime erişim sorununu çözmekten uzak durumsal bir yaklaşım olmuştur. Dolayısıyla bu çalışmanın en önemli bulgusu, Türkiye'de, başta mevsimlik tarımda olmak üzere çocuk işçiliğini azaltarak veya tamamen ortadan kaldırarak çocukların eğitime erişimlerini sağlamak, yaşları gereği çocukluklarını yaşamalarını ve sağlıklı beslenmelerini sağlamak için kurumsal bir model önermesinde bulunması ve böylesi bir modelin ortaya çıkmasına tartışma zemini oluşturmasıdır.

\section{KAYNAKLAR}

Avşar, Z. \& Öğütoğulları, E. (2012). Çocuk İşçiliği ve Çocuk İşçiliği ile Mücadele Stratejileri. Sosyal Güvenlik Dergisi, 2 (1), $9-40$.

Benek, S. \& Ökten, Ş. (2011). Mevsimlik Tarım İşçilerinin Yaşam Koşullarına İlişkin Bir Araştırma: Hilvan İlçesi (Şanlıurfa) Örneği. Gaziantep Üniversitesi Sosyal Bilimler Dergisi, 10 (2). 653-676.

Benek, S. \& Uluç, M., (2017), “Şakha” Belgeseli (Kısa belgesel film, Yönetmen: Sedat Benek-Mustafa Uluç), Yapım: Harran Üniversitesi Sosyal Bilimler Meslek Yüksek Okulu Radyo ve TV Programcılı̆̆ı, Şanlıurfa.

Çalışma ve Sosyal Güvenlik Bakanlığı (ÇSB), (2017), Çocuk İşçiliği İle Mücadele Ulusal Programı, Çalışma ve Sosyal Güvenlik Bakanlığı - Çalışma Genel Müdürlüğü, (2017). https://www.csgb.gov.tr/medias/11752/cocuk_isciligi_rev_23032017.pdf Erişim Tarihi: 22.08.2018.

Çöpoğlu, M. (2018a). Bir Kısır Döngü: Dünyada ve Türkiye’de Çocuk İşçiliği ve İşsizlik. Anemon Muş Alparslan Üniversitesi Sosyal Bilimler Dergisi. 6(5) 671-685.

Çöpoğlu, M. (2018b). Türkiye'de Çocuk İşçiliği. Iğdır Üniversitesi Sosyal Bilimler Dergisi, 14, 357-398.

Efe, H. \& Uluoğlu, S. A. (2015). Dünyada Çocuk İşçiliğiyle Mücadelede Gelinen Nokta ve Geleceğe Dair Bazı Öngörüler. Eğitim Bilim Toplum Dergisi, 13 (51), 46-72.

Erbay, E. (2013). Türkiye’de Çocuk İşçiliğinin Büyük Resmi. Toplum ve Sosyal Hizmet, 24 (1), 157-167.

Güçlü, S. (2016). Çocukluk ve Çocukluğun Sosyolojisi Bağlamında Çocuk Hakları. Sosyoloji Dergisi. Armağan Sayısı, 1-22.

Gülçubuk, B. (2012). Tarımda Çocuk Emeği Sömürüsü ve Toplumsal Duyarlılık. Çalışma ve Toplum, 2, 75-94.

Gümrükçüoğlu, Y. B. (2014). Mevzuatımızda Çocuk ve Genç İşçilerin Çalışma Yaşamında Korunmasına İlişkin Düzenlemelere Genel Bir Bakış. Dokuz Eylül Üniversitesi Hukuk Fakültesi Dergisi, 15, (Özel Sayı), 481-545.

Günöz, M. (2007). Türkiye’de Çocuk İşçiliği Sorunu ve Çözüm Önerileri. (Uzmanlık Tezi). Ankara: Çalışma ve Sosyal Güvenlik Bakanlığı Türkiye İş Kurumu Genel Müdürlüğü.

Güzel, B. (2016). 21. Yüzyılda Çocuk İşçiliği ile Mücadele İlerleme Raporu. Uluslararası Sosyal Araştırmalar Dergisi, 9 (42), 1993-1998.

http://t24.com.tr/haber/isig-raporundan-cocuk-isci-olumleri-6-yasina-kadar-geriledi,344909; Erişim tarihi: 15.04.2018.

ILO (1999a). Recommendation No. 190 on the Prohibition and Immediate Action for the Elimination of the Worst Forms of Child Labour. 87th International Labour Conference (ILC) Session, 17 June 1999 (Geneva).

ILO (1999b). Convention No. 182 on the Elimination of the Worst Forms of Child Labour. 87th International Labour Conference (ILC) Session, 17 June 1999 (Geneva).

ILO (2008). Resolution concerning statistics of child labour. 18th International Conference of Labour Statisticians (ICLS), 24 November-5 December 2008 (Geneva).

ILO (2011). Convention No. 189 Concerning Decent Work for Domestic Workers. 100th International Labour Conference session, 16 June 2011 (Geneva).

ILO (2012). ILO Global Estimate of Forced Labour - Results and Methodology. ILOSpecial Action Programme to Combat Forced Labour (SAP-FL). (Geneva).

ILO (2013). Global Estimates of Child Labour. Results and Trends, 2000-2012. International Labour Office (ILO), Geneva.

ILO (2017). Global Estimates of Child Labour. Results and Trends, 2012-2016. International Labour Office (ILO), Geneva.

ILO-IPEC (2002). Every Child Counts - New Global Estimates on Child Labour. ILO International Programme on the Elimination of Child Labour (IPEC). (Geneva, ILO). 
ILO (2021). Child Labour: Global Estimates 2020, Trends and the Road Forward, ILO and UNICEF, New York.. https://www.ilo.org/wcmsp5/groups/public/---ed_norm/---ipec/documents/publication/wcms_797515.pdf Erişim Tarihi: 1 Aralık 2021.

Kalkınma Atölyesi (2016). Bereketli Topraklar Zehir Gibi Yaşamlar: Suriyeli Göçmen Mevsimlik Gezici Tarım Iş̧̧ileri Adana Ovası Mevcut Durum Araştırma Raporu.

Karaman, B. \& Özçalık, M. (2007). Türkiye’de Gelir Dağılımı Eşitsizliğinin Bir Sonucu: Çocuk İşgücü, Yönetim ve Ekonomi Dergisi, C.14, S.1, s.25-41.

Karataş, K. \& Attepe Özden, S. vd. (2016). Ankara Sokaklarında Çalıştırılan Çocuklar: Sorunlar ve İhtiyaçlar Raporu, Aile ve Sosyal Politikalar İl Müdürlüğ̈̈, Anıl Grup Matbaacılık Yayıncılık.

Küçükkalay, A.M. \& Dulupçu, M.A. \& Turunç, Ö. (2000). Dünyada ve Türkiye'de Çocuk İşücü İstihdamının Sorunları ve Önlenmesi. Süleyman Demirel Üniversitesi İdari ve Íktisadi Bilimler Fakültesi Dergisi, 5(1), 103-118.

Mevsimlik Tarım İşçileri Yuvarlak Masa Toplantısı, (2016). 7. Mevsimlik Tarım İşçileri Yuvarlak Masa Toplantısı Sonuç Raporu, İstanbul.

Şahankaya, A. (2018). Türkiye'de Yeni Prekarya Suriyeli İşgücü mü?. Çalışma ve Toplum. 1, 13-36.

Şanlıurfa İl Milli Eğitim Müdürlüğü, (2019). Mevsimlik Gezici Tarım İşçisi Öğrencileri Takip Ekibi Haziran Raporu

Şanlıurfa Mevsimlik Tarım İşçileri İzleme Kurulu (ŞAMTİ), (2018), Şanlıurfa Mevsimlik Tarım İşçileri Raporu, Şanlıurfa.

TUİK. (2020). Çocuk İşgücü Anketi Sonuçları, 2019 https://data.tuik.gov.tr/Bulten/Index?p=Child-Labour-Force-Survey-201933807Erişim Tarihi: 1 Aralık 2021.

Tunçcan, N. (2000). Çocuk İşçiliği: Nedenleri, Boyutları ve Küreselleşen Dünyadaki Konumu. Sosyal Siyaset Konferansları Dergisi, 43-44, 243-259.

Yandık, F. M. (2017). Türkiye’de Kayıt Dışı İstihdamın Gelir Vergisi Hasılatı Üzerindeki Etkisi. (Yayımlanmamış Yüksek Lisans Tezi). Aydın: Adnan Menderes Üniversitesi, Sosyal Bilimler Enstitüsü.

Yıldız, Ö. (2007). Çalışan Çocuklar: ‘Sorun’ mu? ‘Çözüm’ mü?. Gaziantep Üniversitesi Sosyal Bilimler Dergisi, 6 (2), $57-66$. 